\title{
Biodiesel Formation via the Transesterification of Treated Waste Cooking Oil Using Chicken Eggshell Ash and Natural Zeolite as Solid Catalyst
}

\author{
Taslim*, Nike Taruna, Meilia, Iriany, and Okta Bani \\ Department of Chemical Engineering, Faculty of Engineering, \\ Universitas Sumatera Utara, Medan 20155, Indonesia \\ ORCID: 0000-0003-0482-320X
}

\begin{abstract}
:
In the present work, an attempt had been made to utilize chicken eggshells ash and natural zeolite as a promising catalyst for biodiesel formation. Solid chicken eggshells ash (CEA) was produced through the calcination of chicken eggshells. The CEA was mixed with natural zeolite at a mass ratio of 1:3. This mixture was then used as catalyst in biodiesel formation. Biodiesel was sunthesized via the transesterification of treated waste cooking oil (TWCO) with methanol at temperature of $55-65^{\circ} \mathrm{C}$, methanol to TWCO molar ratio (MTMR) of 8:1-14:1, reaction time of 90-210 min, and catalyst load of $6-10 \%$. The properties of biodiesel obtained were measured such as methyl ester content, flash point, density, viscosity, and compared to the European Standard (EU 14214). The highest yield of $96.8 \%$ was occurred at a MTMR of $12: 1,65^{\circ} \mathrm{C}, 180$ minutes, and $8 \mathrm{wt} \%$ of catalyst load. The results of this study confirmed that natural zeolite addition could improve the catalytic activity of CEA. Therefore, the combination of CEA and natural zeolite may be used as a low-cost catalyst in biodiesel formation.
\end{abstract}

Keywords: calcination, chicken eggshells ash, natural zeolite, transesterification, treated waste cooking oil

\section{INTRODUCTION}

Transesterification is a process to synthesize vegetable oil into biodiesel using methanol and base catalyst. The use of WCO in biodiesel formation will reduce the disposal problem [1] and raw material cost while use of heterogeneous catalyst will ease product separation, allow reusing [2], and reducing energy demand. Deriving heterogeneous catalyst from waste will further reduce operation cost. One such waste is chicken eggshells which main component is calcium carbonate. During calcination of eggshells, the carbonate converts into calcium oxide $(\mathrm{CaO})$, and its activity enhances based on the surface structure. $\mathrm{CaO}$ is a greatly potential base catalyst, and also less soluble in methanol [3].

The investigation of $\mathrm{CaO}$ derived from biomass as solid-base catalyst in transeterifcation reaction had been conducted by several researchers $[4,5,6]$, in which the biodiesel yield was 83-95\%. Generally, heterogeneous catalysts suffer some disadvantages, such as catalyst deactivation caused by poisoning and leaching [3,7]. For $\mathrm{CaO}$ in particular, it is susceptible to impurities such as $\mathrm{CO}_{2}$ and water $(\mathrm{H} 2 \mathrm{O})$ which may block its active site. $\mathrm{CaO}$ will react with $\mathrm{CO}_{2}$ and $\mathrm{H}_{2} \mathrm{O}$ to produce calcium hydroxide and calcium carbonate which reduce the catalytic activity of $\mathrm{CaO}$. These disadvantages of $\mathrm{CaO}$ catalyst can be overcome by using support [3]. One possible support is natural zeolite. Zeolite is a mesoporous compound which contains various metal oxides and can be utilized to support base and transition metal [8]. Adding support allows the catalyst to disperse on the surface and inside of the zeolite, thus improving the catalytic activity of the catalyst [9]. The use of pure $\mathrm{CaO}$ and synthetic zeolite had also been studied by $\mathrm{Wu}$ et al. [10] which yielded up to $95 \%$ of methyl ester by using irradiation method. The impregnation and irradiation methods were believed to be some methods to increase catalytic-activity of $\mathrm{CaO}$ and overcome the disadvantages above.

The application of natural zeolite as catalyst support for $\mathrm{KOH}$ and $\mathrm{K} 2 \mathrm{CO} 3$ has been studied by some researches [11,12]. However, the application of natural zeolite as catalyst support for $\mathrm{CaO}$ or CEA has never been conducted. In this work, natural zeolite was used to increase the catalytic-activity of CEA. This method requires less energy and less chemicals in catalyst preparation (such as in the impregnation or the irradiation method). The aim of this study was to investigate the ability of natural zeolites as catalyst support for CEA and its application in transesterification reaction.

\section{MATERIALS AND METHODS}

\section{II.I. MATERIALS}

In this work, waste cooking oil (WCO) was collected from local food stall located in Sumatera Street, Medan Indonesia. Waste chicken eggshells was provided by food court in Faculty of Engineering, Universitas Sumatera Utara. Activated carbon and methanol were purchased from Merck. The natural zeolite used in this work was obtained from Tapanuli Sumatera Utara, Indonesia.

\section{II.II. PRETREATMENT OF WCO}

Activated carbon as much as $10 \%$ by weight was used to treat WCO in a stirred flask at $300 \mathrm{rpm}$ for 30 minutes. After settling, the solids were filtered out, and the filtrate was treated waste cooking oil (TWCO). Before the transesterification process, physical properties of the TWCO such as free fatty acid (FFA), viscosity, and density were measured. The composition of TWCO was analyzed using gas chromatography (GC). 


\section{II.III. PREPARATION OF CATASYST}

Preparation of catalyst adopted the procedures carried out by Fayyazi et al. [5] with some modifications. The chicken eggshells were cleaned with distilled water. After that, the eggshells was dried for 240 minutes in an oven at $110 \mathrm{oC}$. The dried eggshells were pulverized to 200 mesh in a mill. Calcination of the eggshells was conducted in a muffle furnace at $1000^{\circ} \mathrm{C}$ for 120 minutes to make chicken eggshells ash (CEA). Meanwhile, natural zeolite was also pulverized to 200 mesh in a mill. Afterwards, the zeolite was ready for use as CEA catalyst support. The catalyst used for transesterfication in this work was a mixture of CEA and natural zeolite at mass ratio of 1:3. The catalyst was characterized by SEM/EDX for its morphology and composition. Before application, the catalyst was kept in a tightly closed bottle.

\section{II.IV. TRANSESTERIFICATION}

Transesterification process followed the procedure carried out by Taslim et al. [13]. Fifty grams of TWCO was introduced into a flask. The flask equipped with stirrer, condenser, and thermometer. The flask was heated on hot plate to designated temperature which ranged from $55-65^{\circ} \mathrm{C}$. Methanol, at MTMR of 8:1-14:1 and catalyst load at $6-10 \%$ of TWCO were fed into the flask. The reactants were then homogenized using a stirrer at $600 \mathrm{rpm}$. Times of reaction were varied from 90 up to 210 minutes. The biodiesel obtained was filtered to separate the catalyst. Then, the liquid product was filled into a separator funnel and allowed to form two layers. The bottom layer was drained. The top layer (crude methyl ester) was then extracted using hot water to separate excess catalyst, by product and unreacted reactants. The extraction step was repeated until the drained water became clear. The methyl ester was dried at $105^{\circ} \mathrm{C}$ to remove water. Finally, the methyl ester (biodiesel) was weighed and measured for its methyl ester content, flash point, density, and viscosity according to American Standard Testing and Material (ASTM).

\section{RESULTS AND DISCUSSION}

\section{III.I. PRETREATMENT OF WCO}

In this study, WCO was treated using activated carbon to produce TWCO. The role of this treatment was to reduce impurities and free fatty acid. The results of fatty acid composition of TWCO is shown in Table 1. From Table 1, it can been seen that oleic acid had the highest composition i.e. $44.9953 \%$ of the total fatty acid composition. During pretreatment step, free fatty acid content was reduced by $68 \%$ from the initial composition into $0.45 \%$, allowing it to be used as feedstock for transesterification.

Table 1. Composition of TWCO

\begin{tabular}{ll}
\hline Fatty acid & Composition $(\%)$ \\
\hline Eicosenoic acid (C20:1) & 0.1395 \\
Arachidic acid (C20:0) & 0.3474 \\
Linolenic acid (C18:3) & 0.2174 \\
Linoleic acid (C18:2) & 9.6922 \\
Oleic acid (C18:1) & 44.9953 \\
Stearic acid (C18:0) & 3.9210 \\
Palmitoleic acid (C16:1) & 0.1629 \\
Palmitic acid (C16:0) & 39.2970 \\
Miristic acid (C14:0) & 0.9069 \\
Lauric acid (C12:0) & 0.3204 \\
\hline
\end{tabular}

\section{III.II. CATALYST CHARACTERIZATION}

From Fig 1a, it was observed that CEA (after 102 minutes calcination at $1000{ }^{\circ} \mathrm{C}$ ) had particle size of 2-4 $\mu \mathrm{m}$. The CEA had more orderly surface and its particle size reduced. The particle size reduction can be observed directly from the size distribution under same magnification. The alteration in size and structure of the eggshells might be due to conversion of $\mathrm{CaCO}_{3}$ to $\mathrm{CaO}$ during calcination. Based on EDX result, CEA contained $93.78 \% \mathrm{CaO}$. The $\mathrm{CaO}$ content is very close to that reported in the literature that is at $94 \%$ [14].

Fig 1b presents the morphology of natural zeolite (NZ) which was irregular, contained lots of sharp edges and large pores. Fig 1c presents the morphology of CEA/natural zeolite catalyst mix, in which CEA blended into the natural zeolite surface. In other words, the CEA was dispersed on the surface and inside of the zeolite. This catalyst mix has a size of $1-20 \mu \mathrm{m}$.
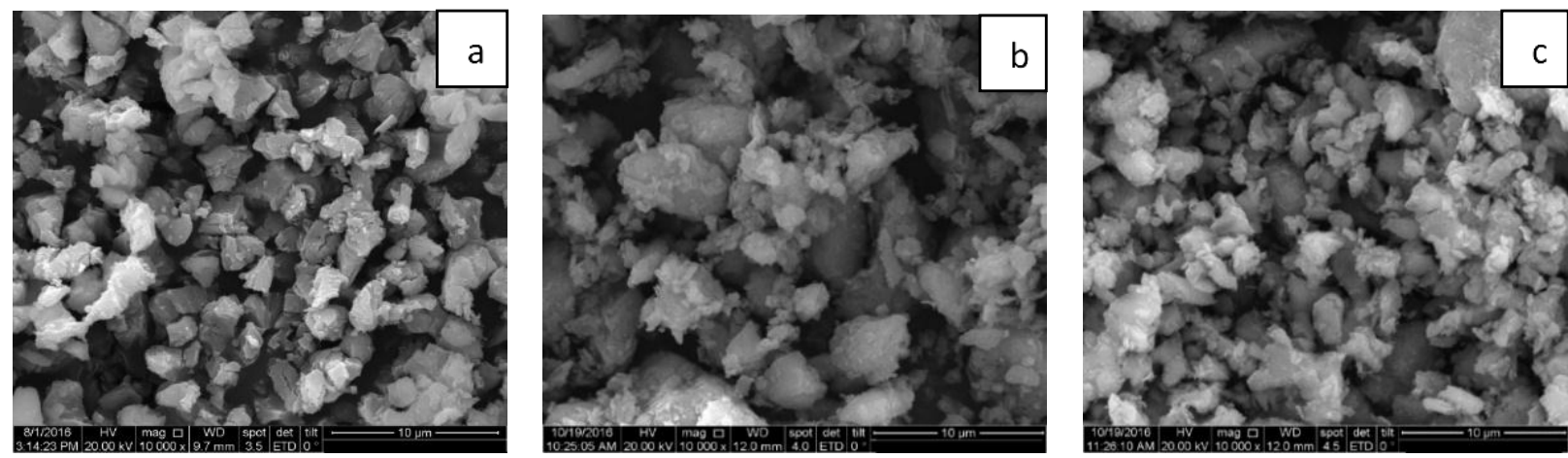

Fig 1. SEM results at 10,000 time magnification of (a) CEA, (b) Natural zeolite, (c) CEA/natural zeolite mix 
Based on EDX results, the composition of CEA, natural zeolite (NZ), and CEA/NZ are displayed in Table 2.

Table 2. Composition of CEA, NA, and CEA/NZ mix

\begin{tabular}{ccccc}
\hline No. & Compound $(\%)$ & $\mathrm{CEA}$ & \multicolumn{1}{c}{$\mathrm{NZ}$} & $\mathrm{CEA} / \mathrm{NZ}$ mix \\
\hline 1. & $\mathrm{CaO}$ & 93.78 & 13.61 & 5.11 \\
2. & $\mathrm{MgO}$ & 0.37 & 0.78 & 0.68 \\
3. & $\mathrm{CuO}$ &. .0 .12 & 1.62 & 1.36 \\
4. & $\mathrm{C}$ & 4.72 & 11.61 & 18.80 \\
5. & $\mathrm{Na}_{2} \mathrm{O}$ & - & 0.93 & 1.19 \\
6. & $\mathrm{Al}_{2} \mathrm{O}_{3}$ & - & 11.02 & 10.66 \\
7. & $\mathrm{SiO}_{2}$ & - & 54.40 & 58.21 \\
8. & $\mathrm{~K}_{2} \mathrm{O}$ & - & 3.89 & 3.12 \\
9. & $\mathrm{FeO}$ & - & 2.13 & 1.61 \\
\hline
\end{tabular}

\section{III.III. TRANSESTERIFICATION}

\section{III.III.1. Effect of reaction time}

Fig 2 shows the reaction times affect biodiesel yield at various MTMR. The variation of reaction time on biodiesel yield was performed at constant MTMR, catalyst load of $8 \%$, catalyst composition (CEA:Zeolite) $1: 3$ and temperature of $65^{\circ} \mathrm{C}$. The reaction time was observed from 90 to 210 minutes. As seen on Fig 2, at a fixed MTMR and increasing reaction time, the biodiesel yield would increase. This yield increased until reaction time of 180 minutes, and decreased afterwards. A prolonged reaction time might lead to overheating of the reaction mixture, greater solvent losses and energy losses. Transesterification is a reversible reaction, yield of the biodiesel will decrease if longer reaction time is used. Similar result was also reported by Taslim et al. [15].

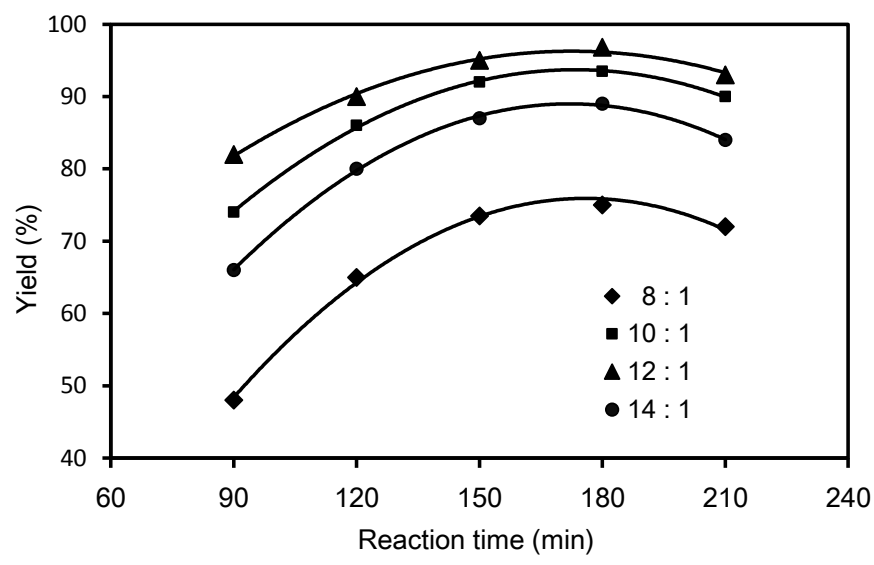

Fig 2. The biodiesel yield versus reaction time at various MTTR, $65 \mathrm{oC}$, and catalyst load of $8 \%$.

The effect of MTTR on biodiesel yield was observed under the same reaction time, catalyst load of $8 \%$, catalyst composition (CEA: Zeolite) 1:3 and temperature of $65^{\circ} \mathrm{C}$. The MTMR affects significantly the biodiesel yield. As seen on Fig 2, at constant reaction time, the biodiesel yield would increase as the MTMR increase although it does not apply to MTMR 14:1 which yield was lower than that of molar ratio 12:1. Generally, higher yield biodiesel is achieved by using excessive alcohol. Higher molar ratio could increase contact between the oil and methanol. However, if the MTMR is too high, it could reduce the yield of biodiesel. This was due to the fact that excessive methanol would dissolve glycerol and this phenomenon would suppress the transesterification of oil to biodiesel [15].

\section{III.III.II. Effect of catalyst load}

Fig 3 shows the catalyst load affect biodiesel yield at various transesterification temperatures. The effect of catalyst load and reaction temperature on biodiesel yield was observed at a fixed MTMR 12:1, catalyst composition (CaO:zeolite) 1:3, and for 180 minutes. The amount of catalyst was varied from 6 to $10 \%$ wt to the TWCO introduced into reactor.

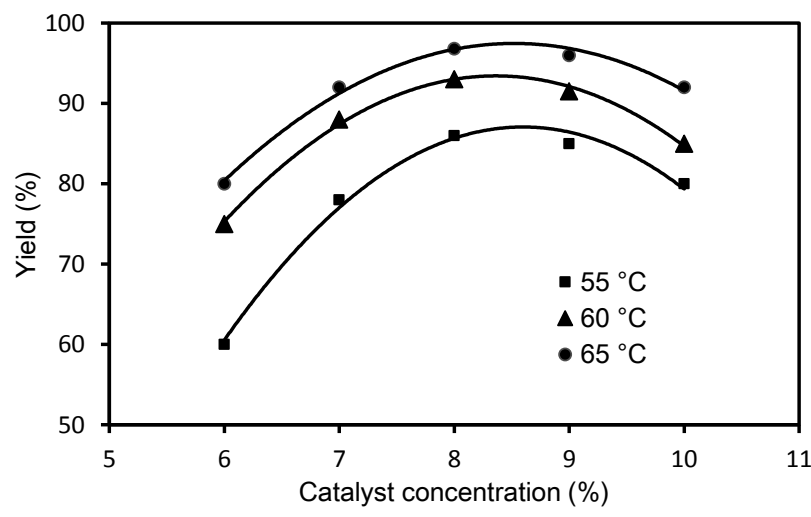

Fig 3. The biodiesel yield versus catalyst load at various temperatures, 180 minutes, and MTMR 12:1

As seen on Fig 3, at constant reaction temperature biodiesel yield increases with catalyst load. Each graph tends to go upward until a point which it will go downward. For all temperatures tested, biodiesel yield kept increasing with catalyst load till the use of $8 \%$ wt. At constant catalyst load, biodiesel yield enhanced with reaction temperatures. Using higher temperatures might shorten the reaction time needed. But, if the temperature is more than the boiling point of the solvent, volatilization of solvent (methanol) will occur, which will increase the vapour phase and the formation of three phases which leads to reaction limitations and lowering the rate of reaction.

The decreasing of yield after addition of more catalyst might be caused by distorted mixing process between catalyst and the solvent. Addition of more catalyst might increase viscosity of the mixture in the reactor, which will increase the energy needed to meet the requirement of efficient mixing, and so the reaction could not be conducted well. The same phenomena were also reported by some researchers $[15,16]$. Besides, too little catalyst might not catalyze the transesterification reaction $[15,17]$. The best yield of $96.8 \%$ was occurred at catalyst load of $8 \%$, transesterification temperature of $65^{\circ} \mathrm{C}$, 
and MTMR of 12:1. The results obtained are higher than those reported by several researchers $[4,5,6,7]$ with the highest yield of $83-95 \%$. However, they used $\mathrm{CaO}$ catalyst without natural zeolite.

\section{III.III.III. Biodiesel Properties}

Table 3 displays some biodiesel properties from this research and their comparison with European standard (EN 14214). As listed in Table 3, the methyl ester product had met the standard requirement as biodiesel. Methyl ester was generated from reaction at MTTR 12:1, $65 \mathrm{C}$, for 180 minutes, in the presence of $8 \%(\mathrm{wt})$ of loaded catalyst.

Table 3. Comparison of biodiesel properties obtained in this research with the EN 14214

\begin{tabular}{lccc}
\hline Biodiesel properties & Unit & This research & EN 14214 \\
\hline Ester content & $\%$ & 99.70 & $>96,5$ \\
Density & $\mathrm{kgm}^{-3}$ & 870.00 & $860-900$ \\
Kinematic viscosity & $\mathrm{mm}^{2} \mathrm{~s}^{-1}$ & 4.22 & $3.5-5.0$ \\
Flash point & ${ }^{\circ} \mathrm{C}$ & 150.00 & $101(\mathrm{~min})$ \\
\hline
\end{tabular}

\section{CONCLUSION}

The present study has evaluated the potential of addition natural zeolite to CEA, which has high prospect as green catalyst in biodiesel formation from TWCO. The highest yield of $96.8 \%$ was achieved by using $12: 1 \mathrm{MTMR}$ at $65^{\circ} \mathrm{C}$, for 180 minutes, in the presence of $8 \%(\mathrm{wt})$ of loaded catalyst, and weight ratio of natural zeolite to CEA was $3: 1$. This yield was higher than that obtained using $\mathrm{CaO}$ or CEA catalyst without natural zeolite. The result of this work showed that natural zeolite addition could improve the catalytic activity of CEA.

\section{REFERENCES}

[1] S.E. Mahesh, A. Ramanathan, K.M.M.S. Begum, and A. Narayanan, Biodiesel production from waste cooking oil using $\mathrm{KBr}$ impregnated $\mathrm{CaO}$ as catalyst, Energy Conversion and Management, 91, 2015, 442450 .

[2] I.M. Atadashi, M.K. Aroua, A.R. Abdul Aziz, and N.M. Nik Sulaiman, Production of biodiesel using high free fatty acid feedstocks, Renewable and Sustainable Energy Reviews, 16 (5), 2012, 3275-3285.

[3] D.M. Marinkovic, M.V. Stankovic, A.V. Velickovic, J.M. Avramovic, M.R. Miladinovic, O.O. Stamenkovic, V.B. Veljkovic, and D.M. Jovanovic, Calcium oxide as a promising heterogenous catalyst for biodiesel production: Current state and perspectives, Renewable and Sustainable Energy Reviews, 56(C), 2016, 1387-1408.

[4] M. Kouzu, T. Kasumo, M. Tajika, Y. Sugimoto, S. Yamanaka, and J. Hidaka, Calcium oxide as a solid base catalyst for transesterification of soybean oil and its application to biodiesel production, Fuel, 87, 2008, 2798-2806.

[5] E. Fayyazi, B. Ghobadian, H.H. van de Bovenkamp, G. Najafi, B. Hosseinzadehsamani, H.J. Heeres, and J. Yue, Optimization of biodiesel production over chicken eggshell-derived $\mathrm{CaO}$ catalyst in a continuous centrifugal contactor separator, Industrial \& Engineering Chemistry Research, 57, 2018, 1274212755.

[6] Z. Wei, C. Xu, and B. Li, Application of waste eggshell as low-cost solid catalyst for biodiesel production, Bioresource Technology, 100, 2009, 28832885 .

[7] M. Verziu, S.M. Coman, R. Richards, and V.I. Parvulescu, Transesterification of vegetable oils over $\mathrm{CaO}$ catalyst, Catalyst Today, 167, 2011, 64-70.

[8] R.J. Davis, New perspectives on basic zeolites as catalysts and catalyst support, Journal of Catalysis, 216, 2003, 396-405.

[9] S. Yan, H. Lu, and B. Liang, Supported $\mathrm{CaO}$ catalysts used in the transesterification of rapeseed oil for the purpose of biodiesel production, Energy Fuels, 22, 2008, 646-651.

[10] H. Wu, J. Zhang, Q. Wei, J. Zheng, and J. Zhang. Transesterification of soybean oil to biodiesel using zeolite supported $\mathrm{CaO}$ as strong base catalysts, Fuel Processing Technology, 109, 2013, 13-18.

[11] Taslim, Iriany, O. Bani, S.Z.D.M. Parinduri, and P.R.W. Ningsih, Biodiesel production from rice bran oil using heterogeneous catalyst modified with $\mathrm{K}_{2} \mathrm{CO}_{3}$, IOP conference series: Materials Science and Engineering, 309, 2018, 012107.

[12] Taslim, Iriany, O. Bani, S.Z.DM. Parinduri, P.R.W. Ningsih, and N. Taruna, Preparation, characterization and application of natural zeolite form Tapanuli Indonesia modified with $\mathrm{KOH}$ as catalyst support for transeterification of rice bran oil, International Journal of Engineering Research and Technology, 12 (9), 2019, 1452-1456.

[13] Taslim, O. Bani, Iriany, N. Aryani, and G.S. Kaban, Preparation of activated carbon-based catalyst from candlenut shell impregnated with $\mathrm{KOH}$ for biodiesel production, Key Engineering Materials, 777, 2018, 262-267.

[14] W. Stadelman, Encyclopedia of Food Science and Technology (New York: John Wiley and Sons, 2000), 593-599.

[15] Taslim, O. Bani, Iriany, S. Lestari, and L. Ginting, Biodiesel production using heterogeneous catalyst based on volcanic ash of Mount Sinabung, AIP Conference Proceedings, 2085, 2019, 020062.

[16] A.M. Dehkordi, and M. Ghasemi, Transesterification of waste cooking oil to biodiesel using $\mathrm{Ca}$ and $\mathrm{Cr}$ 
International Journal of Engineering Research and Technology. ISSN 0974-3154, Volume 13, Number 3 (2020), pp. $433-437$

(C) International Research Publication House. https://dx.doi.org/10.37624/IJERT/13.3.2020.433-437

mixed oxides as heterogenous base catalyst, Fuel Processing Technology, 97, 2012, 45-51.

[17] P. Khemthong, C. Luadthong, W. Nualpaeng, P. Changsuwan, P. Tongprem, N. Viriya-empikul, and K. Faungnawakij, Industrial eggshell wastes as the heterogeneous catalysts for microwave-assisted biodiesel production, Catalysis Today, 190, 2012, 112116. 